\title{
Sarcoidosis and autoimmune hemolytic anemia: is there a pathogenic link?
}

\author{
Chifa Damak ${ }^{1}$, Mouna Snoussi ${ }^{1}$, Faten Frikha ${ }^{1}$, Donia Chebbi ${ }^{1}$, Moez Jallouli ${ }^{1}$, Raida Ben Salah ${ }^{1}$, Hanen Loukil ${ }^{1}$,
} Sameh Marzouk ${ }^{1}$, Zouhir Bahloul ${ }^{1}$

\begin{abstract}
The association between sarcoidosis and AlHA is extremely rare. Herein, we report a novel case of this association in which will focus on the pathogenesis and the prognosis. Mr. A. F., a 43 year old patient was presented to internal medicine department in November 2007 with bilateral inguinal adenopathies. The diagnosis of sarcoidois was made on the basis of identification of granulomas in salivary biopsy with the negativity of other etiological investigations. He was treated with steroids with favorable outcome. Seven years later, he was presented with deep autoimmune hemolytic anemia which was not related to sarcoidoisis. He was again put on steroids with favorable evolution.
\end{abstract}

Keywords: autoimmune hemolytic anemia therapy, autoimmune hemolytic anemia, corticotherapy

\section{INTRODUCTION}

Sarcoidosis is a systemic disease of unknown etiology characterized by non-caseating granulomas, affecting any organ in the body. Recent research uncovered underlying immunological and genetic mechanisms (1). Auto-immune hemolytic anemia (AIHA) occurs when autoantibodies target antigens on red blood cells. It may be secondary to malignant lymphoproliferative disorders, viral infections, drugs, and other autoimmune disorders. Nonetheless, most cases are idiopathic (2). The association between sarcoidosis and AlHA is extremely rare. Herein, we report a novel case of this association in which we will focus on the pathogenesis and the prognosis.

\section{CASE REPORT}

Mr. A. F., a 43 year old patient presented to internal medicine department in November 2007 with bilateral inguinal adenopathies. He had no significant medical history. Physical examination was normal apart from inguinal adenopathies. Complete blood count was within normal. No significant laboratory findings were present: erythrocyte sedimentation rate was $23 \mathrm{mmH} 1$, the liver enzymes were within the normal levels and the renal function as well. The calcium and phosphate levels were respectively $2.32 \mathrm{mmol} / \mathrm{l}$ and $1 \mathrm{mmol} / \mathrm{l}$ and there was no hypercalciuria. The chest X-ray showed mediastinal enlargement. In the thoraco-abdomino-pelvic scan there were multiple mediastinal, abdominal adenopathies and reticulonodular interstitial pattern of the lung. Respiratory function tests identified a restrictive syndrome. The Histopathological examination of salivary glands indicated that there is granulomas and the angiotensin converting enzyme level was normal. Accordantly, the diagnosis of systemic sarcoidosis was made. The patient had been treated with high dose of prednisone $(1 \mathrm{mg} / \mathrm{kg} /$ day) during four weeks followed by a slow tapering. Favorable clinical and biological outcome were noticed.

In August 2014, the patient presented with recent deep asthenia and drowsiness. On the physical examination, he was looking pale and experienced tachycardia and there was no peripheral adenopathies or splenomegaly. Biological investigations concluded to regenerative anemia at $4.9 \mathrm{~g} / \mathrm{dl}$ normocytic normochromic. The LDH and indirect bilirubin levels were three folds increased. Coombs test was positive with warm lg $\mathrm{G}$ antibodies. A viral screen including HIV, EBV,

1 Medical School of Sfax, Tunisia.

Received: 29 Jun 2019, Accepted: 11 Sep 2019
Correspondence: Mouna Snoussi

Medical School of Sfax, Tunisia.

(c) $\mathbf{2 0 2 0}$ by the authors; licensee Modestum Ltd., UK. This article is an open access article distributed under the terms and conditions of the Creative Commons Attribution License (http://creativecommons.org/licenses/by/4.0/). 
and CMV and a mycoplasma serology were negative. Antinuclear antibodies were negative. Systemic sarcoidosis was considered in remission. The diagnosis of idiopathic AlHA was retained. The patient was treated with high dose of corticosteroids ( $1 \mathrm{mg} / \mathrm{kg} /$ day) initiated with three pulses of methylprednisolone $(1 \mathrm{~g} /$ day) with favorable evolution. In in his subsequent follow-up, there were no relapses of both diseases.

\section{DISCUSSION}

We report a rare association of systemic sarcoidosis and idiopathic AIHA. To the best of our knowledge, only 13 cases were reported in the literature (2-4,6-10). Other cases reported a sarcoidosis with AlHA and additional affections as thrombocytopenia (11), Hodgkin (12), non-Hodgkin lymphoma (13) Sjögren's syndrome (11) and Massive splenomegaly with pancytopenia (14). Since the first report of the association in 1954, it was unclear if it is a coincidence or if there is a possible pathogenic link (2).

Sarcoidosis occurs because of an unidentified antigen is presented to T-lymphocytes by antigen-presenting cells. The interaction leads to the activation of an inflammatory response through a Th1 cells, the recruitment of inflammatory cells and the formation of non caseating granulomas. More recently, there is a compelling evidence for a role of Th17 immune pathways in the generation and maintenance of sarcoidosis granulomas (15).AlHA pathogenesis begins with the presence of immunoglobulin $\mathrm{G}$ antibodies reacting with protein antigens on the surface of red blood cells at normal body temperature mediated by Th1 bias $(10,16)$. So, Th1 cells are responsible for the initial autoantibody response and that the Th17 cells drive the chronic inflammation in autoimmune conditions including sarcoidosis and AlHA. The triggering antigen in sarcoidosis and other autoimmune diseases provides preferential induction of Th-1 type CD4 cells and down regulation of Th-2 type cells which may gives rise to potential autoimmunity (17). These shared immunopathogenic processes between sarcoidosis and AlHA may explain this association and suggest a therapeutic strategy (2).

Treatment is not always necessary in sarcoidosis. The mainstay of treatment of sarcoidosis is steroids with generally a good response. The use of corticosteroids systemic therapy in sarcoidosis is indicated in serious extrapulmonary involvement, e.g. hypercalcemia, cardiac, central nervous system and hepatic, or in interstitial pulmonary involvement with respiratory symptoms and/or clinically significant impairment of lung function. Immunosuppressant therapy as methotrexate and azathioprine are indicated in refractory form of the disease (18).

The first line treatment of AIHA is glucocorticoids. Second-line therapy includes immunosuppressives, cytotoxic agents, splenectomy, and intravenous gamma globulin. Rituximab is an effective alternative treatment because it reduces the local Th17 response incriminated in the immunopathology of the disease (10). Our patient was treated with steroids for both his sarcoidosis and his hemolytic anemia.

\section{CONCLUSION}

The association of sarcoidosis and autoimmune haemolytic anaemia is very rare. It may be explained by the similar pathological basis involving Th1 and Th17 lymphocytes. There are no guidelines on how to treat sarcoidosis with AlHA. First line treatment is glucocorticoids for both pathologies with a good response in our case.

\section{REFERENCES}

1. Chernow K, Donegan T, Milman T, Henry D. Sarcoidosis, complete heart block, and warm autoimmune hemolytic anemia in a young woman. J Community Support Oncol., 2015 Apr;13(4):159-61. https://doi.org/10.12788/jcso.0128 PMid:26102609

2. Davis AE, Belber JP, Movitt ER. The association of hemolytic anemia with sarcoidosis. Blood, 1954 Apr;9(4):37983. https://doi.org/10.1182/blood.V9.4.379.379 PMid:13149623

3. Yasuda N, Kohda M, Nomura M, et al. Sarcoidosis in a patient with autoimmune hemolytic anemia. Nihon Kyobu Shikkan Gakkai Zasshi, 1996 Aug;34(8):931-6. PMID:8965407

4. Ghaddar RK, Muzaffar TH. Pulmonary sarcoidosis and autoimmune hemolytic anemia: possible common immune pathogenesis. Arch Iran Med., 2011 Mar;14(2):146-8. https://doi.org/011142/AIM.0015 PMID:21361724

5. Chernow K, Donegan T, Milman T, Henry D. sarcoidisis, complete heart block, and warm autoimmune hemolytic anemia in a young woman, J Community Support Oncol., 2015 Apr;13(4):159-61. https://doi.org/10.12788/jcso.0128 PMid:26102609 
6. Desablens B, Pruna A, Gontier MF, Messerschmitt J. Autoimmune haemolytic anaemia associated with bone marrow sarcoidosis,. Acta Haematol. 1984;71(3):204-6. https://doi.org/10.1159/000206585 PMid:6424385

7. Wyss S, Maier C. Hemolytic anemia in sarcoidosis of the spleen. Acta Haematol., 1967;37(2):126-36. https://doi.org/10.1159/000209060 PMid:4963236

8. Meregalli $\mathrm{M}$, Bosisio $\mathrm{R}$, Delpiano $\mathrm{CL}$, Spinelli $\mathrm{M}$. Monolateral sarcoidosis of parotid gland associated with hemolytic anemia: description of a case diagnosed by cytohistology. Haematologica, 1991 Jul-Aug;76(4):321-3. PMID:1794738

9. Thadani U, Aber CP, Taylor JJ. Massive splenomegaly, pancytopenia and haemolytic anaemia in sarcoidosis. Acta Haematol., 1975;53(4):230-40. https://doi.org/10.1159/000208188 PMid:808933

10. Green S, Partridge E, Idedevbo E, Borg A. Steroid Refractory Autoimmune Haemolytic Anaemia Secondary to Sarcoidosis Successfully Treated with Rituximab and Mycophenolate Mofetil. Case Rep Hematol.,2016;2016:9495761. https://doi.org/10.1155/2016/9495761 PMid:27563474 PMCid:PMC4985568

11. Kondo H, Sakai S, Sakai Y. Autoimmune haemolytic anaemia, Sjögren's syndrome and idiopathic thrombocytopenic purpura in a patient with sarcoidosis. Acta Haematol., 1993;89(4):209-12. https://doi.org/10.1159/000204526 PMid:8213004

12. Spitzer T, Crum E, Schacter L, Abboud S. Sarcoidosis, Hodgkin's disease, and autoimmune hemolytic anemia. Am J Med Sci., 1986 Mar;291(3):190-3. https://doi.org/10.1097/00000441-198603000-00010 PMid:3953637

13. Taillan B, Pedinielli FJ, Routy JP, Blanc AP. Non-Hodgkin malignant lymphoma and autoimmune anemia during the development of sarcoidosis. Rev Med Interne., 1985 Dec;6(5):573-5. https://doi.org/10.1016/S02488663(85)80040-0

14. Paul S, Gupta V, Gonsalves WI, Kochuparambil ST, Gangat N. Sarcoidosis Presenting with Pancytopenia. Am J Med., 2014 Sep;127(9). https://doi.org/10.1016/j.amjmed.2014.05.031 PMid:24927908

15. Chiarchiaro J, Chen BB, Gibson KF. New molecular targets for the treatment of sarcoidosis. Curr Opin Pulm Med., 2016 Sep;22(5):515-21. https://doi.org/10.1097/MCP.0000000000000304 PMid:27454074 PMCid:PMC5152532

16. Barcellini W. New Insights in the Pathogenesis of Autoimmune Hemolytic Anemia. Transfus Med Hemother, 2015;42:287-93. https://doi.org/10.1159/000439002 PMid:26696796 PMCid:PMC4678320

17. Ghaddar RK, Muzaffar TH. Pulmonary Sarcoidosis and Autoimmune Hemolytic Anemia: Possible Common Immune Pathogenesis. Arch Iran Med., 2011 Mar;14(2):146-8. https://doi.org/011142/AIM.0015 PMID:21361724

18. Grutters JC, van den Bosch JMM. Corticosteroid treatment in sarcoidosis. Eur Respir J, 2006;28:627-36. https://doi.org/10.1183/09031936.06.00105805 PMid:16946094

$$
\diamond \diamond \diamond \diamond \diamond \diamond \diamond
$$

http://www.ejgm.co.uk 